\title{
NOTES ON RARE, VAGRANT AND EXOTIC AVIFAUNA AT MACQUARIE ISLAND, 1901-2000
}

\author{
by G. R. Copson and N. P. Brothers \\ (with one text-figure and three tables)
}

\begin{abstract}
Copson, G. R. \& Brothers, N. P. 2008 (31:x): Notes on rare, vagrant and exotic avifauna at Macquarie Island, 1901-2000. Papers and Proceedings of the Royal Society of Tasmania 142(1): 105-116. https://doi.org/1 26749/rstpp.142.1.105 ISSN 008-4703. 32 Red Chapel Ave, Sandy Bay, Tasmania 7005, Australia (GRC*), 176 South Arm Drive, Wonga Beach, Queensland 4873, Australia (NPB). *Author for correspondence.

The occurrence and status of rare, vagranr and exotic bird taxa recorded at Macquarie Island between 1901 and 200 are reviewed. The number of species recorded at the island, excluding rhose that have bred regularly on the main island between 1901 and 200 , is increased to 56 non-breeding species, seven species that have been confirmed breeding since 198 and four introduced/exotic species breeding on the island.
\end{abstract}

Key Words: Macquarie Island, sub-Antarctic, avifauna records.

\section{INTRODUCTION}

Sub-Antarctic Macquarie Island (fig. 1) lies in the Southern Ocean, at $54^{\circ} 30^{\prime} \mathrm{S}, 158^{\circ} 57^{\prime} \mathrm{E}$, approximately $1500 \mathrm{~km} \mathrm{SSE}$ of Hobart, Tasmania, and $1100 \mathrm{~km}$ SSW of Invercargill, New Zealand. The nearest land is the Auckland Islands, $600 \mathrm{~km}$ $\mathrm{NE}$ and Campbell Island $650 \mathrm{~km}$ ENE. The island is $34 \mathrm{~km}$ long by $5.5 \mathrm{~km}$ at its broadest point and 12800 ha in area. There are two small outlying groups, the Judge and Clerkislets $11 \mathrm{~km}$ to the north and the larger Bishop and Clerk islets $37 \mathrm{~km}$ to the south, together with several offshore sea stacks around the main island. Macquarie Island rises steeply from the sea to an undulating plateau, ranging between $200 \mathrm{~m}$ and $300 \mathrm{~m}$ above sea level, having a maximum altitude of 433 $\mathrm{m}$. The northwestern part of the island is fringed by a raised beach-terrace up to $800 \mathrm{~m}$ broad and $15 \mathrm{~m}$ above sea level.

The climate is extreme oceanic with a mean monthly temperature of $3.8^{\circ} \mathrm{C}$, precipitation on 312 days of the year with an annual mean of $920 \mathrm{~mm}$, average humidity of $89 \%$ and an average wind speed of $33.4 \mathrm{kph}$ with over $70 \%$ of the wind coming from within the southwest to northwest quadrant (De Lisle 1965, Selkirk et al. 1990).

Since its discovery by sealers in 1810 , several species of exotic fauna have been either deliberately or accidentally introduced onto the island. By the end of the nineteenth century the Feral Cat, Felis catus Linnaeus, 1758, Weka, Gallirallus australis (Sparrman, 1786), European Rabbit, Oryctolagus cuniculus (Linnaeus, 1758), House Mouse, Mus musculus Linnaeus, 1758, and Black Rat, Rattus rattus (Linnaeus, 1758), had become established (Cumpston 1968, Jenkin et al. 1981). In addition, other exotic species became established on the island after dispersing from their introduction sites in Australia and/or New Zealand. In the twentieth century Common Redpoll, Acanthis flammea (Linnaeus, 1758), Common Starling, Sturnus vulgaris Linnaeus, 1758, and Northern Mallard, Anas platyrhynchos platyrhynchos Linnaeus, 1758, became established on Macquarie Island in such a manner (Falla 1937, Norman 1987).

The direct impact of the sealers combined with the introduction of terrestrial vertebrates led to major changes in the status of species of the indigenous flora and fauna. The earliest detailed studies of the fauna occurred with Scott's

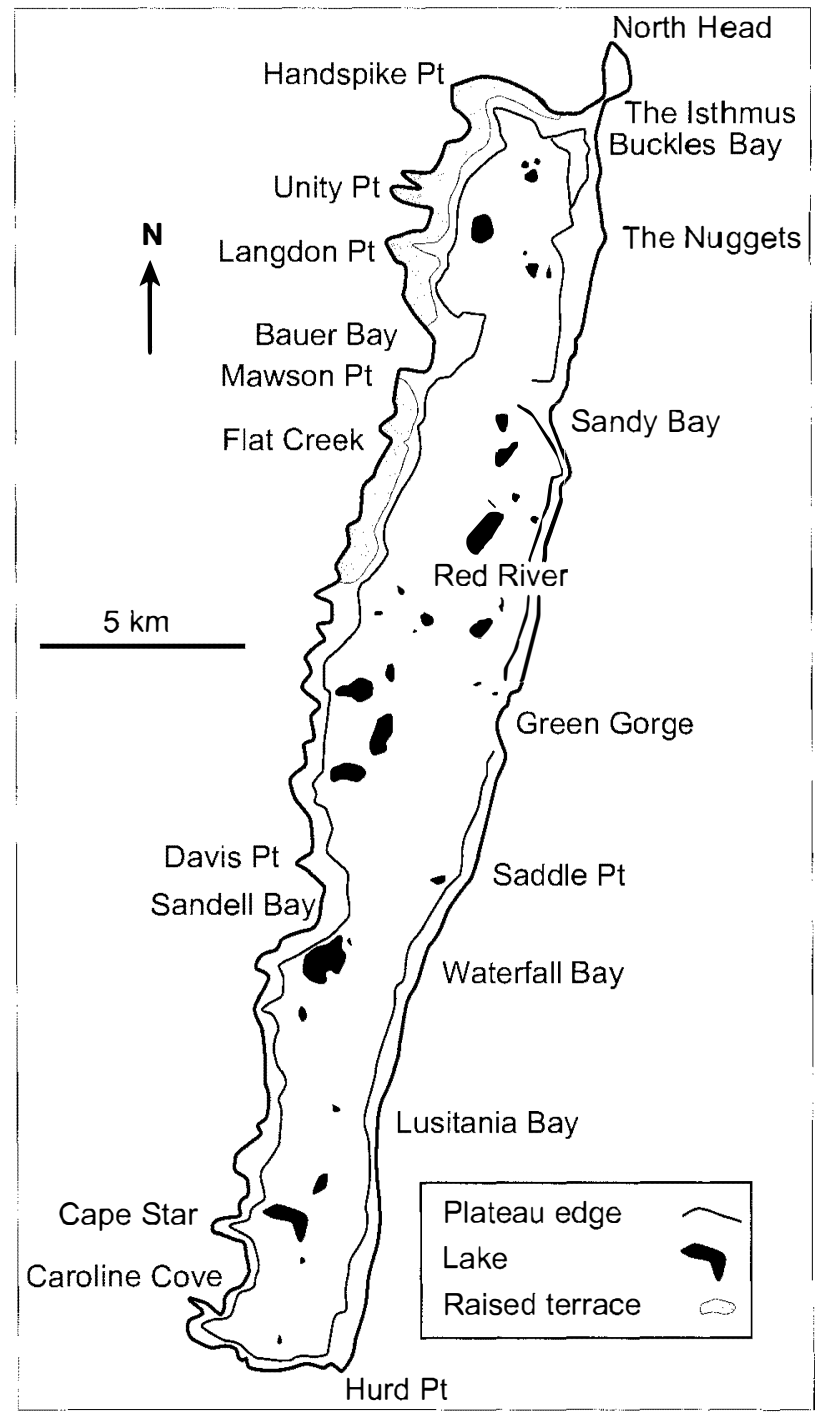

FIG. 1 - Macquarie Island localities referred to in the text. 
visit in 1880 , Burton's records of the avifauna between 1896 and 1900 and H. Hamilton's work during the Australasian Antarctic Expedition 1911-14 (AAE), i.e., after several of the exotic species had become well established ( $S$ cott 1883, Campbell 1901, Mawson 1930, Falla 1937). Little is known therefore of the island's flora, fauna and ecosystems in their pristine state.

The establishment of an Australian National Antarctic Research Expeditions (ANARE) Station on the island in 1948 has resulted in studies, of the highest order, in a broad range of scientific disciplines including the biological sciences. In addition the continuous staffing of the island since 1948 has resulted in the accumulation of incidental observations which will, given a sufficient time span, become valuable data. The bird records below are an example of this.

\section{METHODS}

The records are all from the period 1901-2000 and include a wide range of published and unpublished sources. It was considered that 2000 was an appropriate time to finish the review as the vertebrate pest management program being undertaken, together with climate change, are likely to have increasing impacts on the status of both the indigenous and vagrant avian species at the islands over the next decades. During the period covered Macquarie Island was occupied by sealers/penguin oil industry workers intermittently up to 1920, the AAE and Australian Bureau of Meteorology staff from 1911-15 and ANARE personnel continuously from 1948. The great majority of the records are from the AAE, effectively 1912-13, and ANARE periods covering approximately 54 years.

Nineteen avian species that are considered native to Macquarie Island and known to have bred more or less continuously on the island over the period considered are not included in the review. Species whose breeding has been proven only in the last few years of the records are included. All exotic species, i.e., the deliberately introduced Weka together with the self-introduced northern hemisphere species, have been included whether breeding or not on the island. Domestic stock taken to the island during the AAE and some early ANARE years are not included.

In order to give an indication of the frequency of visitation for each taxon, tables 1-3 show the number of years in which they have been recorded at the island.

Numbers in brackets following each note indicate the source of the record. These are: 1. Hamilton 1912-13; 2 . Falla 1937; 3. Serventy 1952; 4. Lindholm 1952; 5. Gwynn 1953; 6. Keith \& Hines 1958; 7. Gibson 1959; 8. Warham 1961; 9. Simpson 1965, 10. Warham 1969; 11. Merilees 1971a; 12. Merilees 1971b; 13. Bourne 1981; 14. Brothers 1984; 15. Brothers \& Ledingham 2008; 16. Brothers \& Bone 2008; 17. Unpublished ANARE, Tasmanian Parks and Wildlife Service (PWS) and Department of Primary Industries and Water logbooks and records.

In the text any reference to Macquarie Island includes the off-lying sea stacks, the Judge and Clerk islets and the Bishop and Clerk islets unless otherwise indicated. Observations from re-supply vessels out to $10 \mathrm{~km}$ have been included.

The systematics and taxonomy largely follows Christidis \& Boles (2008). All records have been entered onto a spreadsheet including, as far as possible, the date, location, observer/s, numbers recorded and any notes for each taxon. Copies of the spreadsheet will be lodged with the Australian Antarctic Division, Tasmanian Department of Primary Industries and Water and Tasmanian Parks and Wildlife Service.

\section{RECORDS 1901-2000}

\section{Vagrant and regular visiting species}

\section{Australian Shelduck, Tadorna tadornoides (Jardine \& Selby, 1828)}

A single female Australian Shelduck was sighted amongst tussock in the Caroline Cove area in December 1990. In 1998, on 30 January, a male and three females were sighted on a small lake in Red River and on 13 February a male and four females were seen at the same site [17].

Grey Teal, Anas gracilis Buller, 1869

While the first positive record was in 1957 there appear to have been several other unrecorded sightings of this species between 1948 and 1957. There are also three records from 1979 when three birds were seen in. April and one in May at Green Gorge and one sighted in the Red River area in September $[6,17]$.

\section{Hoary-headed Grebe, Poliocephalus poliocephalus} (Jardine \& Selby, 1927)

In 1975 sightings of single birds were made in August (2), September (1) and October (2) while in November two birds were seen together. All sightings were at the same site, a small pool at Green Gorge [17].

Rock Dove, Columba livia J.F. Gmelin, 1789

This is a record of a banded bird which was released in a race from Victoria to Tasmania on the morning of 29 October 1989 and caught at the ANARE Station, on The Isthmus, on 31 October 1989 [17].

Fork-tailed Swift, Apus pacificus (Latham, 1802)

On 11 December 1958 a Swift was seen over the Royal Penguin colonies at The Nuggets but could not be positively identified. On 12 December a clearview of a Fork-tailed Swift was obtained around North Head. The only other records of this species were of one seen on 27 November 1975 at Perseverance Bluff, the southern end of The Isthmus, and one seen about $2 \mathrm{~km}$ north, in the Secluded Beach area, on the next day $[7,17]$.

\section{White-throated Needletail, Hirundapus caudacutus (Latham, 1802)}

Between 1960 and 1992 there were 25 sightings, totalling over 46 birds, of this species at Macquarie Island. The first record is of one collected in January 1960. The next records were in the summer of 1969-70 when seven sightings each of a single bird were recorded between 26 December 1969 and 10 February 1970 . From 19 January to 11 February 1971 there were ten sightings of up to six birds recorded. Further sightings occurred in 1977 (1), 1979 (2), 1980 (1), 1985 (1) and 1992 (3). While the majority of these were in January or February one bird was sighted just south of The Nuggets on 9 March 1977 and two at Hurd Point on 24 April 1985 [8, 10, 17]. 
TABLE 1

Non-breeding birds recorded at Macquarie Island, 1901-2000

\begin{tabular}{|c|c|c|c|c|c|c|c|c|c|c|c|c|c|}
\hline \multirow[t]{2}{*}{ Species } & \multicolumn{12}{|c|}{ Number of birds recorded in month ${ }^{1}$} & \multirow{2}{*}{$\begin{array}{l}\text { No. years } \\
\text { recorded }\end{array}$} \\
\hline & $\mathrm{J}$ & $\mathrm{F}$ & $\mathrm{M}$ & A & $\mathrm{M}$ & $\mathrm{J}$ & $\mathrm{J}$ & $A$ & $S$ & $\mathrm{O}$ & $\mathrm{N}$ & $\mathrm{D}$ & \\
\hline Australian Shelduck & 4 & 5 & - & - & - & - & - & - & - & - & - & 1 & 2 \\
\hline Grey Teal & - & - & - & 3 & 1 & - & - & - & 1 & - & - & 1 & 2 \\
\hline Hoary-headed Grebe & - & - & - & - & - & - & - & 2 & 1 & 2 & 2 & - & 1 \\
\hline Emperor Penguin & - & 1 & 1 & - & - & - & - & - & - & - & - & - & 2 \\
\hline Adelie Penguin & 1 & - & - & - & - & - & - & - & - & - & 1 & 1 & 3 \\
\hline Chinstrap Penguin & 8 & 4 & 5 & - & - & - & - & - & - & 1 & 14 & 7 & 23 \\
\hline Snares Penguin & 2 & 3 & 1 & - & - & - & - & - & - & - & 1 & - & 4 \\
\hline Erect-crested Penguin & 8 & 25 & 8 & 2 & 1 & - & - & - & - & 6 & 2 & 4 & 23 \\
\hline Southern Fulmar & 2 & - & - & - & - & - & - & - & 6 & 5 & $7+$ & 6 & 12 \\
\hline Antarctic Petrel & 5 & - & - & - & - & - & - & 1 & 1 & 1 & 4 & 1 & 5 \\
\hline Snow Petrel & - & - & - & - & - & 1 & 1 & $2+$ & - & - & - & - & 3 \\
\hline Soft-plumaged Petrel & 2 & - & - & - & - & - & - & 1 & - & 1 & $16+$ & 2 & 4 \\
\hline Mottled Petrel & 1 & - & - & - & - & - & - & - & - & - & - & - & 3 \\
\hline Slender-billed Prion & - & - & 1 & - & 1 & 1 & - & - & 1 & - & 1 & - & 3 \\
\hline Westland Petrel & 1 & - & - & - & - & - & - & - & - & - & - & - & 1 \\
\hline Short-tailed Shearwater & 2 & - & - & 1 & - & - & - & - & - & - & 4 & - & 4 \\
\hline Shy Albatross & 1 & - & - & - & - & - & - & - & - & - & - & 1 & 1 \\
\hline Salvin's Albatross & - & - & - & - & - & - & - & - & - & - & - & 1 & 1 \\
\hline Sooty Albatross & - & - & - & - & - & - & - & - & - & - & 1 & 1 & 2 \\
\hline Grey-backed Storm Petrel & - & - & - & 1 & - & - & - & - & 4 & - & 2 & - & 4 \\
\hline Australian Gannet & 1 & - & - & - & - & - & - & - & 1 & - & - & - & 2 \\
\hline Great Cormorant & 68 & $48+$ & 66 & 4 & 1 & - & - & - & - & 12 & 47 & $94+$ & 7 \\
\hline White-faced Heron & - & 1 & 8 & $7+$ & 17 & 7 & 2 & 5 & $4+$ & 1 & 1 & 3 & 10 \\
\hline Little Egret & - & - & - & 2 & - & - & - & - & - & - & - & - & 2 \\
\hline Eastern Great Egret & - & - & - & 5 & - & 1 & - & - & - & - & - & - & 3 \\
\hline Intermediate Egret & - & - & 2 & - & 1 & - & - & - & - & - & - & - & 1 \\
\hline Cattle Egret & - & - & - & 15 & 1 & 1 & - & 1 & - & - & - & - & 9 \\
\hline Swamp Harrier & - & 1 & - & - & - & 1. & - & - & 1 & 2 & 1 & - & 4 \\
\hline Baillon's Crake & 1 & - & - & - & - & - & - & - & - & - & - & - & 1 \\
\hline Eurasian Coot & 1 & - & - & - & 1 & 2 & - & 2 & 2 & 2 & - & - & 5 \\
\hline Latham's Snipe & 1 & - & - & - & - & - & - & - & - & - & 2 & 3 & 6 \\
\hline Bar-tailed Godwit & - & - & - & - & - & - & - & - & - & 1 & - & 1 & 2 \\
\hline Common Greenshank & - & - & - & - & - & - & - & - & - & - & - & - & 1 \\
\hline Ruddy Turnstone & 4 & - & - & - & - & - & - & - & $?$ & 1 & - & 25 & 5 \\
\hline Great Knot & - & - & - & - & - & - & - & - & - & 1 & - & - & 1 \\
\hline Red Knot & - & - & - & - & - & - & - & - & - & - & 1 & 6 & 2 \\
\hline Red-knecked Stint & - & - & - & - & - & - & - & - & - & 4 & - & - & 1 \\
\hline Curlew Sandpiper & 2 & - & - & - & - & - & - & - & - & - & - & - & 1 \\
\hline Red-knecked Phalarope & 2 & - & - & - & - & - & - & - & - & - & - & 3 & 2 \\
\hline Pied Oystercatcher & 1 & - & - & - & - & - & - & - & - & - & 3 & - & 2 \\
\hline Black-winged Stilt & - & - & - & 1 & 14 & - & - & - & - & - & - & - & 1 \\
\hline Grey Plover & - & 1 & - & - & - & - & - & - & - & - & - & 1 & 2 \\
\hline Lesser Sand Plover & 7 & - & - & - & - & - & - & - & - & - & - & - & 1 \\
\hline Black-fronted Dotterel & - & - & - & - & - & - & - & - & 2 & 1 & 1 & - & 3 \\
\hline Masked Lapwing & - & 2 & - & - & 4 & - & - & - & 18 & 3 & $?$ & 5 & 6 \\
\hline Arctic Tern & 3 & - & - & - & - & - & - & - & - & - & 4 & - & 3 \\
\hline Rock Dove & - & - & - & - & - & - & - & - & - & 1 & - & - & 1 \\
\hline Pallid Cuckoo & - & - & - & - & - & - & - & - & 1 & - & - & - & 1 \\
\hline White-throated Needletail & $30+$ & $11+$ & 1 & 2 & - & - & - & - & - & - & - & 2 & 9 \\
\hline Fork-tailed Swift & - & - & - & - & - & - & - & - & - & - & 2 & 1 & 2 \\
\hline European Goldfinch & - & - & - & 1 & 3 & - & - & - & - & - & - & - & 3 \\
\hline Welcome Swallow & $1+$ & - & $?$ & 25 & 4 & - & - & - & 2 & 3 & 5 & - & 9 \\
\hline Tree Marcin & - & - & - & - & - & - & - & - & 1 & 1 & - & - & 2 \\
\hline Silvereye & - & - & - & - & 2 & - & - & - & 1 & 1 & 1 & - & 2 \\
\hline Common Blackbird & - & - & 1 & 4 & 4 & 3 & $4+$ & 11 & 8 & 1 & 3 & - & 11 \\
\hline Song Thrush & - & - & - & - & 1 & - & 4 & 8 & 7 & $2+$ & - & - & 8 \\
\hline
\end{tabular}

1. Numbers of birds recorded each month include re-sights. 
TABLE 2

Rare and exotic breeding birds at Macquarie Island, 1901-2000

\begin{tabular}{|c|c|c|c|c|c|c|c|c|c|c|c|c|c|c|}
\hline \multirow[t]{2}{*}{ Species } & \multicolumn{12}{|c|}{ Number of birds recorded in month ${ }^{1}$} & \multirow{2}{*}{$\begin{array}{l}\text { No years } \\
\text { recorded }\end{array}$} & \multirow[t]{2}{*}{ Status $^{2}$} \\
\hline & $J$ & $\mathrm{~F}$ & M & A & $\mathrm{M}$ & $\mathrm{J}$ & $\mathrm{J}$ & A & $\mathrm{S}$ & $\mathrm{O}$ & $\mathrm{N}$ & $\mathrm{D}$ & & \\
\hline Northern Mallard & \multicolumn{12}{|c|}{ Recorded throughout the year } & 31 & $b$ \\
\hline Common Diving-Petrel & 1 & - & 3 & 5 & $2+$ & - & - & - & 2 & $1+$ & - & - & 13 & $\mathrm{~b}$ \\
\hline $\begin{array}{c}\text { South Georgian } \\
\text { Diving-Petrel }\end{array}$ & - & - & - & - & 1 & - & - & - & 2 & - & - & 4 & 3 & $b$ \\
\hline Cape Petrel & 2 & 5 & 2 & $8+$ & 70 & 6 & 11 & $117+$ & $145+$ & $147+$ & $91+$ & $14+$ & 23 & $b$ \\
\hline Fairy Prion & - & - & - & - & $?$ & - & - & - & $2+$ & $2+$ & - & - & 3 & $b$ \\
\hline Fulmar Prion & - & - & 1 & - & - & - & - & 5 & - & - & - & - & 2 & $b$ \\
\hline Grey Petrel & - & - & 3 & 8 & 5 & 2 & - & 1 & - & - & 1 & - & 10 & $b$ \\
\hline Wilson's Storm-Petrel & - & - & - & - & - & - & - & - & - & - & - & 4 & 1 & $\mathrm{~b}$ \\
\hline Weka & \multicolumn{12}{|c|}{ Recorded throughout the year until 1988} & 43 & ext \\
\hline Common Redpoll & \multicolumn{12}{|c|}{ Recorded throughout the year } & 54 & B \\
\hline Common Starling & \multicolumn{12}{|c|}{ Recorded throughout the year } & 52 & $\mathrm{~B}$ \\
\hline
\end{tabular}

${ }_{1}$ Numbers of birds recorded each month include re-sights.

${ }^{2} \mathrm{~B}=$ more than 150 breeding pairs; $\mathrm{b}=$ fewer than 150 breeding pairs; ext = extinct.

TABLE 3

Doubtful bird identifications at Macquarie Island, 1901-2000

\begin{tabular}{|c|c|c|c|c|c|c|c|c|c|c|c|c|c|}
\hline \multirow[t]{2}{*}{ Species } & \multicolumn{12}{|c|}{ Number of birds recorded in month } & \multirow{2}{*}{$\begin{array}{l}\text { No years } \\
\text { recorded }\end{array}$} \\
\hline & $\mathrm{J}$ & $\mathrm{F}$ & M & A & $\mathrm{M}$ & $\mathrm{J}$ & $\mathrm{J}$ & A & $\mathrm{S}$ & $\mathrm{O}$ & $\mathrm{N}$ & $\mathrm{D}$ & \\
\hline $\begin{array}{c}\text { Double-banded } \\
\text { Dotterel }\end{array}$ & - & - & - & - & - & - & - & - & - & 1 & - & - & 1 \\
\hline Hooded Plover & 4 & - & - & - & - & - & - & - & - & - & - & - & 1 \\
\hline Little Tern & - & - & - & - & - & - & - & - & - & - & - & 1 & 1 \\
\hline Richard's Pipit & - & - & - & - & - & - & 1 & - & - & - & - & - & 1 \\
\hline
\end{tabular}

Grey-backed Storm-Petrel, Garrodia nereis (Gould, 1841)

Grey-backed Storm Petrels have been recorded at Macquarie Island five times, seven birds in all. A female in breeding condition was collected in September 1956 while in 1979 and 1990 birds were attracted to the lights on The Isthmus and released after identification. Two were recorded in 2000 $[6,14,15]$.

Shy Albatross, Thalassarche cauta (Gould, 1841) The first sighting, January 1989, was from the stern of the resupply vessel, MV Polar Queen, approximately $5 \mathrm{~nm}$ northwest of the ANARE Station. The ship was manoeuvering slowly, while searching for a wave recorder buoy and had attracted several species of birds close up. In December 1989 the species was again recorded scavenging around Killer Whales, Orcinus orca (Linnaeus, 1758), close inshore at Sandy Bay [17].

\section{Salvin's Albatross, Thalassarche cauta salvini} (Rothschild, 1898)

The Bishop and Clerk islets, $37 \mathrm{~km}$ south of the main island, were visited for only the third time in December 1993. During this visit a Salvin's Albatross was seen amongst the Blackbrowed Albatross, Thalassarche melanophris (Temminck, 1828), which breed on the islets [15].

\section{Sooty Albatross, Phoebetria fusca (Hilsenberg,} 1822)

Single birds were recorded in December 1975 and November 1978. The 1975 bird had landed on the southern slopes of Cape Star, on the west coast, while the 1978 record was of a bird $0.5 \mathrm{~km}$ offshore around Douglas Point [17].

\section{Southern Fulmar, Fulmarus glacialoides (A. Smith, 1840)}

Southern Fulmars were recorded at Macquarie Island in 12 separate years between 1956 and 2000 . Sightings and collections were from many sites around the island. Ten of the 24 records were of beach-washed material and specimens, with most others being of birds flying close inshore. In December 2000 a bird was caught at The Isthmus and released later $[6,17]$.

Antarctic Petrel, Thalassoica antarctica (J.F. Gmelin, 1789)

All records of this species were of beach-washed material which was found on both sides of the island. Over five years $(1970,1974,1978,1980$ and 2000) the remains of eight birds were found with single records on six occasions, two birds on 16 January 2000 and three on 27 January 2000 and two pairs of wings being found together in 1980 [17]. 
Snow Petrel, Pagadroma nivea (G. Forster, 1777) Snow Petrels were recorded in August 1968 when several were reported in Buckles Bay. In July 1994 the remains of one were found at the southwestern part of the island and in November 2000 an injured bird was found on The Isthmus 17].

\section{Slender-billed Prion, Pachyptila belcheri (Mathews, 1912)}

Single birds of this species were recorded five times between 1976 and 2000. In March 1976, one was caught on The Isthmus, measured and released. In May 1979, one was found in a burrow on Langdon Point sea stack and in September 1979 one was at a burrow entrance on Davis Point sea stack and on two occasions in 2000 dead birds were found on The Isthmus $[14,17]$.

\section{Westland Petrel, Procellaria westlandica Falla, 1946}

There is only one record of this species, of a single bird close to the re-supply ship MV Polar Queen while it was anchoring in Buckles Bay [17].

\section{Short-tailed Shearwater, Puffinus tenuirostris (Temminck, 1835)}

There are seven records, from four years between 1960 and 1979, of single specimens of this species. Four records are from November, two from January and one from April, with four being beach-washed birds, one found freshly dead and one in a skua bolas. The April record was of a bird regurgitated, almost intact, by a Light-mantled Sooty Albatross, Phoebetria palpabrata (J. R. Forster, 1785), chick, while it was being checked on a nest, and could therefore have been collected by the parent bird some distance from the island $[10,14,17]$.

\section{Soft-plumaged Petrel, Pterodroma mollis (Gould, 1844)}

The remains of a Soft-plumaged Petrel were found in a Great Skua, Stercorariusskua lonnbergi (Mathews, 1912), territory at Saddle Point in 1979. A dead adult was also found at Saddle Point in November 1993, as well as dead birds at two places along the south coast, two at Green Gorge and one at Brothers Point. Also three burrows were found along the south coast in 1993. In October 1982 and August 2000, birds were caught during spotlighting at Green Gorge. In January 2000, a dead bird was found at Saddle Point while in November of that year a flock of $12+$ was seen off North Head following the re-supply vessel MV Polarbird [16, 17].

\section{Mottled Petrel, Pterodroma inexpectata (J. R.}

Forster, 1844)

In 1956 a cranium found was identified as this species. Bourne (1981) questions this identification suggesting that it is a Soft-plumaged Petrel. One seen offshore at North Head in 1994 and a beach-washed specimen was found in Half Moon Bay in 1996 [6, 13, 17].

\section{Emperor Penguin, Aptenodytes forsteri Gray, 1844}

Emperor Penguins have been recorded only twice at Macquarie Island; one bird was seen at Green Gorge on 5 March 1993 and a second at Sandy Bay on 21 February 1997. Both appeared to be juvenile birds [17].
Adelie Penguin, Pygoscelis adeliae (Hambron \& Jacquinot, 1841)

Three Adelie Penguins have been recorded on the island, one each in November 1950, December 1963 and January 1997. All were sighted on The Isthmus with the 1963 bird remaining at Landing Beach for three days. The 1950 bird was collected (Melbourne Museum No. B4121) [5, 17].

\section{Chinstrap Penguin, Pygoscelis antarcticus (J. R.} Foster, 1781)

This species has been recorded 38 times in 23 years between 1953 and 1997. Only on one occasion were two birds seen together. Birds were recorded in all months between October and March with the most records (14) being in November. Moulting birds were noted in January, February and March. A bird banded at Dumont d'Urville on 14 February 1977 was sighted on The Nuggets beach on 23 November 1980 $[6,17]$.

\section{Snares Penguin, Eudyptes pachyrhynchus robustus (Oliver, 1953)}

In four years between 1950 and 1979 there were seven records of this species, involving eight birds. A female, thought to have been in breeding condition, was recorded on 3 November 1957; however, egg laying is normally completed earlier than this. Immature birds were recorded moulting in February 1950, February 1977 and January 1979 [5, 6, 17].

\section{Erect-crested Penguin, Eudyptes sclateri Buller, 1888}

This species was first recorded in 1912 and was reported in 21 years between 1953 and 1990 and once in 2000. Moulting birds were recorded in February and March during several years. In 1968 birds were found paired with Royal Penguins, Eudyptes schlegeli Finsch, 1876, one at Sandy Bay and another at Flat Creek colonies. In both cases eggs were reported but both failed. Erect-crested Penguins were seen in several years between 1963 and 1987 at the northern Royal Penguin colony, Sandy Bay [2, 6, 10, 17].

\section{Australasian Gannet, Morus serrator (G. R. Gray, 1843)}

There are two records of this species at the island. In January 1977 one was seen from The Isthmus, flying just off Garden Bay. The second was of a single bird flying over The Isthmus in September 1998 [17].

\section{Great Cormorant, Phalacrocorax carbo (Linnaeus, 1758)}

The first report of Great Cormorants was in March 1952, a probable sighting of two birds. In October 1957 an immature bird was seen, and in November 1957 an adult and immature bird were seen at close range. Starting in early October 1976 Great Cormorants were recorded every month until late May 1977. During this period there were 74 sightings recorded totalling approximately 300 birds, with one flock being $30_{+}$ birds. Starting again in early October 1977 and continuing monthly until March 1978 there were 18 records, totalling 40 birds with a maximum flock of nine. It is uncertain whether the break between May and October is real as there were no biologists on the island that winter and sightings may not have been logged. Undoubtedly many of the records from October 1976 to March 1978 were re-sightings of the birds/ flocks. There are two other records, one in November 1979 of 
a single bird out from The Nuggets and the second in January 1992 when two birds were seen at Langdon Point $[6,17]$.

\section{White-faced Heron, Egretta novaehollandiae (Latham, 1790)}

A White-faced Heron was recorded in March 1957 and while there were several subsequent sightings that year details do not appear to have been recorded. A single bird was seen in Secluded Bay in February 1964 and there was a probable sighting of a single bird in February 1968. Sightings, from many parts of the island, occurred every month from late March to early October in 1975, with up to three birds being seen at a time. A pair of birds was seen in December 1975. There were six sightings of single birds, and one bird found dead, in 1976. In 1980 there were three records, two in 1984, one in 1985 and 1987 and two in 1998. In total $56+$ White-faced Herons have been recorded at the island, occurring in all months but January $[6,17]$.

\section{Little Egret, Egretta garzetta (Linnaeus, 1766)}

Little Egrets were recorded in 1986 and 1988. The first was a bird found dead at Hurd Point on 27 April 1986. In 1988 a single bird remained on The Isthmus for four days, 24-28 April. [17].

\section{Eastern Great Egret, Ardea modesta J.E. Gray, 1831}

A bird was sighted in April 1957 which was said to be the second sighting at the island but no previous record has been found. The remains of one was taken from skuas in April 1975, and later identified in Australia, and a second dead bird was found in June that year several kilometres from the first site. In April 1986 there was a possible identification of two at Mawson Point and later that month one was seen on The Isthmus $[2,3,6,17]$.

Intermediate Egret, Ardea intemedia Wagler, 1829

There are two records of Intermediate Egrets on Macquarie Island, the first being in March 1990 when one was seen on the coast just north of Green Gorge. The second was one bird recorded on The Isthmus on 9, 10 and 11 May 1990 [17].

\section{Cattle Egret, Ardea ibis Linnaeus, 1758}

In August 1975 the remains of a Cattle Egret were found on The Isthmus. One was photographed feeding in Garden Bay in April 1977. Two were seen in poor condition in the Red River area on 19 April 1979, then single birds on 20 and 21 and two birds on 24 April a few kilometres south of Red River at Green Gorge. On 7 May 1979 one was found dead at Brothers Lake, a few kilometres north of Red River. One bird was recorded on The Isthmus in April 1985 and two birds were seen there in April 1986. Cattle Egrets were also recorded on 19 and 21 April 1994 at The Isthmus. During a fortnight in 1996, following a very strong easterly wind, several live birds were seen and carcasses found on the plateau. A dead bird was found on The Isthmus in April 1998. A bird sighted at Green Gorge in April 2000 was found dead there a week later. The last record is from the Caroline Cove area on 2 June of that year [17].

\section{Swamp Harrier, Circus approximans Peale, 1848}

A Swamp Harrier was reported flying over North Head in October 1949. In late June 1960 and a few days later in July one was seen on the west coast around Mawson Point. In September of that year there was another sighting, also at
Mawson Point, of a bird that was described as being darker than the earlier records. One was recorded in February 1967 being harassed by terns, at Mawson Point, and in September there was a possible sighting of a single bird at Mawson Point. In 1988 one was recorded in the Eagle Cave area. Both Mawson Point and Eagle Cave are along the broad raised beach-terrace of the northwestern section of the island which is covered by deep marshland associations with sections of tall tussock grass $[5,10,17]$.

\section{Baillon's Crake, Porzana pusilla (Pallas, 1776)}

The only record of this cryptic species is of an exhausted bird being found beside one of the buildings on The Isthmus. The bird was collected and returned to the Australian Antarctic Division for positive identification [17].

\section{Eurasian Coot, Fulica atra Linnaeus, 1758}

A dead Eurasian Coot was collected in May 1957 and six others were seen frequently up to October of that year. Between June and October 1975 a single bird was recorded six times on the same pool at Green Gorge. One was recorded in September 1978 and October 1979 on a lagoon at Langdon Point and the last record is of a single bird again on the pool at Green Gorge in January 1981 [6, 17].

\section{Australian Pied Oystercatcher, Haematopus longirostris Vieillot, 1817}

There are four records of the Australian Pied Oystercatcher at Macquarie Island, three in 1980 and one in 1984. In 1980 one was seen on 3, 8, and 18 of November on The Isthmus. In 1984 a single bird was recorded on the west coast around Aurora Cave [17].

\section{Black-winged Stilt, Himantopus himantopus (Linnaeus, 1758)}

A Black-winged Stilt was photographed on a beach at Green Gorge on 19 April 1976. On 22 and 25 April 1976 seven birds were recorded feeding around rotting kelp on the beach at Hurd Point [17].

Grey Plover, Pluvialis squatarola (Linnaeus, 1758) In February 1984 a bird was seen below Gadget Gully, Buckles Bay. It was collected and returned to Australia where it was positively identified as a Grey Plover. The specimen is in the Melbourne Museum collection. On 5 December 1993 a single bird was sighted in Unity Bay [9, 17].

\section{Lesser Sand Plover, Charadrius mongolus Pallas, 1776}

There is a single record of seven birds seen in Langdon Bay in January 1989 [17].

\section{Black-fronted Dotterel, Elseyornis melanops (Vieillot, 1818)}

Two Black-fronted Dotterel were seen in September 1980 at Unity Point. A single bird was sighted at Landing Beach, The Isthmus, in October 1991 and another single bird in Windsor Bay in November 1993 [17].

Masked Lapwing, Vanellus miles (Boddgert, 1783) The first record was from September 1985 when two were seen near Duck Lagoon. In October 1992 three were recorded on The Isthmus, with a note that three had been seen on the island for several months. Three were again recorded on The Isthmus in December 1992. Two were recorded in February 1993 in 
Hasselborough Bay and two on The Isthmus in December of that year. In 1994 two birds were recorded together at Langdon Point, on 27 and 30 May, and in September two were sighted at The Isthmus and one at Unity Point. There was an unrecorded number of birds at The Isthmus on 2 November 1994. One was found dead at Green Gorge in September 1998, after being seen alive several days before. Four were seen on three occasions in September 2000, twice on The Isthmus and once at Handspike Point [17].

\section{Latham's Snipe, Gallinago hardwickii (J. E. Gray, 1831)}

Probable sightings of this species were reported in November 1949 , on the west coast raised beach-terrace, and in November 1960 on North Head. There have been four other sightings, all of single birds. In December 1974 a bird was flushed just south of Handspike Corner, in December 1975 one was recorded at Green Gorge, in January 1980 one was sighted at Unity Point and in December 1984 one was sighted around tussock grassland on Wireless Hill. In November 1996 a snipe, species unknown, was flushed from tussock by Jessie Niccol Creek $[5,10,17]$.

\section{Bar-tailed Godwit, Limosa lapponica (Linnaeus, 1758)}

One bird, later identified as a Bar-tailed Godwit, was collected in October 1912 by a member of the AAE. A second Bartailed Godwit was collected in December $1951[2,4]$.

\section{Common Greenshank, Tringa nebularia (Gunnerus, 1767)}

In 1962 a Common Greenshank was collected on the island and later deposited in the National Museum of Australia, specimen No. W 6480 [9].

\section{Ruddy Turnstone, Arenaria interpres (Linnaeus, 1758)}

From 1-6 October 1971 there were several sightings of a single bird around Landing Beach on The Isthmus. In December 1976 ten were photographed at Eagle Point. Fifteen Ruddy Turnstone were recorded in Unity Bay on 5 December 1993 and on 16 January 1994 four were sighted just north of Sandy Bay. There was a record of a sighting at Unity Point in September 2000 with a note of previous sightings that year [17].

Great Knot Calidris tenuirostris (Horsfield, 1821)

There is one record of this species from October 1990 when a single bird was seen by the Royal Penguin colony at Jessie Niccol Creek [17].

\section{Red Knot Calidris canutus (Linnaeus, 1758)}

A specimen was collected in November 1913 by the AAE party. On 7 and 13 December 1978 three birds were seen and photographed on Midas Tarn, one of the highland lakes north of Green Gorge [2, 17].

\section{Red-necked Stint, Calidris ruficollis (Pallas, 1776)}

The only record is of a single bird seen and photographed on beaches on both the eastern and western sides of The Isthmus on 3-8 October 1976 [17].

\section{Curlew Sandpiper, Calidris ferruginea} (Pontoppidan, 1763)

In January 1994 two Curlew Sandpipers were recorded just north of Sandy Bay [17].

\section{Red-neck Phalarope, Phalaropus lobatus} (Linnaeus, 1758)

There are five records of a single male in Half Moon Bay between 24 December 1975 and 10 January 1976. Photographs were taken on three occasions [17].

Arctic Tern, Sterna paradisaea Pontoppidan, 1763) Three records have been found of Arctic Terns at the island. Two possible sightings, one of one bird off Buckles Bay in January 1977 and one of four birds in Sandell Bay, on the west coast, in November 1991. In January 1992 two birds were photographed in Unity Bay [17].

Pallid Cuckoo, Cacomantis pallidus (Latham, 1802) One record of a bird collected at Bauer Bay on 23 October 1990 and returned to Australia for identification [17].

\section{Silvereye, Zosterops lateralis (Latham, 1802)}

There is a mention of a Silvereye from 1915 but details of this record cannot be located. The only others recorded at the island are from 1994. There is a record of sightings at The Nuggets and further south at Sandy Bay on 28 May, no numbers are given in either case. Single birds were recorded below Halfway Hill on 17 September and The Isthmus on 4 October. There is also a recorded sighting, but no details, on The Isthmus on 22 November $[2,17]$.

Welcome Swallow, Hirundo neoxena Gould, 1842 Berween 1976 and 1992 there were 25 sightings of this species recorded at the island. In late March and early April 1978 single birds were seen on The Isthmus and at Sandy Bay. In the autumn of 1979 there were sightings of up to four birds at The Isthmus and other parts of the island as well as a single bird at Green Gorge. In May 1980 four immature birds were seen resting on buildings on The Isthmus and in November 1985 there are two records of birds around The Isthmus. Single or pairs of birds were recorded in the autumn of 1986, 1988 and 1992, and in the spring of 1988 and 1992 [17].

Tree Martin, Pterochelidon nigricans Vieillot, 1817 There was a probable sighting of a Tree Martin on the west coast at Bauer Bay in September 1970. In October 1974 one was caught at the radio shack on The Isthmus and returned to Australia for positive identification [17].

Common Blackbird, Turdus merula Linnaeus, 1758 Following unconfirmed sightings in previous years Common Blackbirds werefirst positively identified on Macquarie Island on 31 March 1960 with other sightings at the same site, Bauer Bay, in September of that year. In 1965 there were sightings of single birds, on The Isthmus, 6 June, and at Aerial Cove, $31 \mathrm{July}$, and records of a male and female together on 28 August and 3 September, locations unspecified. In 1965 there were 12 records, starting with the sighting of a male and one other bird south of Lusitania Bay hut on 23 April. All other sightings were of single birds, two in May, one each in June and July, three in August, one in September and three in November. The sightings were well spread around the coastal areas of the island. There was one record for each of 25 May, 
30 June, 21 August and 5 September 1967 of single birds on The Isthmus, together with a sighting of a single bird at The Nuggets on 27 May. In 1970 there were sightings on the west coast, around Bauer Bay, on 23 August and 10 October and one on the east coast at Finch Creek on 2 September. single male was sighted at Caroline Cove on 21 April 1975 and a female was flushed from tussock grassland on 22 July 1976 at Hurd Point. There are two records from 1978; on 18 August a female was seen at the same site in Caroline Cove as the male in 1975 and a male was seen by Bauer Bay hut on 24 August. A single male was recorded at Sandy Bay on 18 September 1979. In 1985 there were three sightings of single birds, a male at Mt Elder on 23 July, a bird at Handspike Corner on 27 July and another in the southwest of the island on 8 August. There are four records, all of single birds, from 1990. A bird was seen at lower Finch Creek, Sandy Bay, on 24 April, another recorded on the southern end of The Isthmus on 27 August, the third, a female, on 6 September at Finch Creek and on the same day another female $3 \mathrm{~km}$ north at Tussock Point $[10,17]$.

Song Thrush, Turdus philomelos C.L. Brehm, 1831 Three Song Thrushes were recorded on 30 August 1967. One was collected and the specimen is in the Melbourne Museum, No B9351. The next record is of two flushed from coastal tussock grassland north of Sandy Bay on 25 August 1976 and photographed in the same area the next day. A bird was sighted on The Isthmus in May 1977 while in 1979 there were five records, one on the east coast north of Green Gorge on 8 August, three sightings at Caroline Cove, southwestern part of the island, from 1 to 7 September and one bird again north of Green Gorge on 13 September. There were sightings of single birds at Green Gorge hut on 12 and 27 July 1985 and at Middle Beach on 23 and 26 July 1985. A record of a sighting at Handspike Point, in October 1994, does not give the number of birds. One was sighted at Secluded Beach in the winter of 1996. On 25 September 2000 there are two records of single birds a few hundred metres apart on the east coast north of Hurd Point and one several kilometres further north at Waterfall Bay. Two birds were seen in the same area at Waterfall Bay on 29 October 2000 [12, 17].

\section{European Goldfinch, Carduelis carduelis (Linnaeus, 1758)}

A male goldfinch was collected on 17 April 1956. A second bird was collected on The Isthmus 5 May 1967. There were two further records both from 1977 when, on 22 May one was seen feeding in tussock grass on The Isthmus, and on 30 May one was seen flying over it $[6,11,17]$.

\section{Rare and exotic breeding species}

\section{Northern Mallard, Anas platyrhynchos platyrhynchos Linnaeus, 1758}

Northern Mallard were first recorded on Macquarie Island in August 1949 when a drake was seen with 25 Pacific Black Duck, Anas superciliosa J.F. Gmelin, 1789, on one of the lakes. From 1964-1970 there were a further 15 sightings recorded, mainly of a single drake with Pacific Black Ducks but on two occasions in 1967 pairs were recorded. There are no further records until June 1975 and from then until the end of the year there were 29 sightings with up to 12 drakes being seen at a time and one duck with nine young. From
1976 to the end of 1980 PWS staff on the island kept more detailed records of this exotic species. Excluding 1977, when the PWS did not have staff on the island over the winter, there were a further 114 records with up to $15+$ Northern Mallard being recorded at a time. In October 1979 a female was flushed off a nest with 12 eggs $[5,11,17]$.

Common Diving-Petrel, Pelecanoides urinatrix (J.F. Gmelin, 1789)

From 1950-1985 this species was recorded 15 times (24 birds) in 13 years. Two females collected on The Isthmus in 1956 were later identified by Bourne (1981) as South Georgian Diving-Petrels. In 1979 ten birds were measured and one bird was found incubating an egg on a sea-stack at Langdon Point. The burrows were searched again in 1988 and 1999 but no birds were found $[6,13,14,15,16]$.

\section{South Georgian Diving-Petrel, Pelecanoides georgicus Murphy \& Harper, 1916}

In 1949 one specimen and in 1956 two specimens of this species were collected on the island (Melbourne Museum Nos. B 4276, M 56/8/123 and 124). The latter two were originally identified as Common Diving-Petrels. In 1993 three birds were found on eggs on Bishop and Clerk islets. In January 2000 a burrow ascribed to this species was found on a very small sea stack off the east coast $[6,13,15,16]$.

\section{Cape Petrel, Daption capense (Linnaeus, 1758)}

The AAE party did not record this species. The first recorded sighting appears to be during the British, Australian, New Zealand Antarctic Research Expedition 1929-1931 (BANZARE) visit on 2 and 3 December 1930 when a small flock was sighted at the north end of the island. In 23 years between 1960 and 2000 there are 98 sightings recorded totalling over 600 birds. These range from beach-washed specimens through many sightings of single birds to flocks of over 50 on four occasions. The bulk of the birds recorded, $500+$, was between August and November, with May having the only other significant numbers, 70 birds (table 1). From the 1960 s it was thought that they may be breeding on offshore sea stacks but no evidence was found until March 1998 when birds were seen on nests around North Head although breeding was not confirmed. Breeding has since been confirmed $[1,2,16,17]$.

\section{Fairy Prion, Pachyptila turtur (Kuhl, 1820)}

A Fairy Prion was collected in breeding condition in September 1956 and the remains of two birds were collected in October 1957. In May, September and October 1979 Fairy Prions were found in burrows on sea stacks off Langdon and Davis points. Twenty-four birds were measured and an egg found in one burrow proved that they breed on the sea stacks. Three birds on eggs and three abandoned eggs were found on Bishop and Clerk islets in the 1993 survey [6, 14, 15, 16].

\section{Fulmar Prion, Pachyptila crassirostris (Mathews, 1912)}

In 1979 a female Fulmar Prion was collected on The Isthmus. The specimen is lodged in the Queen Victoria Museum, Launceston, No. 1877 1980/2/16. During bird surveys in 2000 , measurements from five birds found nesting in a cave on North Head fell within the range given in HANZAB for this species. An egg was found with one of these birds in November 2000. However, either genetic analysis or 
verification from an expert in prion taxonomy is required before it can be safely claimed that Fulmar Prions breed on the island $[14,17]$.

Grey Petrel, Procellaria cinerea J.F. Gmelin, 1789 While members of the AAE did not always identify petrel and prion species they collected, often referring to them as "large or small night birds", skins in the National Museum of Australia (No. 33037) and the O'Connor collection in Wellington, New Zealand, were identified as Grey Petrel by Falla (1937). In ten of the years between 1949 and 1990 Grey Petrel were recorded 15 times, 20 birds in total, often with indications that they may be breeding on the island. During the 1990 s more systematic searches were carried out, as part of a feral pest management program, and in 2000 birds were found breeding on North Head and at Green Gorge. Since then they have been recorded breeding in several other parts of the island $[1,2,6,10,14,17]$.

\section{Wilson's Storm-Petrel, Oceanites oceanicus (Kuhl, 1820)}

Two birds were found on eggs and two birds were found together in a third burrow during the survey of Bishop and Clerk islets in $1993[15,16]$.

\section{Weka, Gallirallus australis (Sparrman, 1786)}

Weka were introduced onto Macquarie Island, from New Zealand, around 1870, although there could have been an earlier introduction in the 1840 s (Cumpston 1968). By the early 1900s they were common and widespread around the island and often caught for food by the people working on the penguin oil industry and AAE members. When a rabbit control program took effect in the early 1980 s Weka numbers dropped rapidly, most likely due to feral cats using them to replace rabbits as a food source. Starting in 1985 the PWS began a program to eradicate the Weka from the island and the last recorded was one shot at Bauer Bay in December $1989[2,17]$

\section{Common Redpoll, Acanthis flammea (Linnaeus, 1758)}

Common Redpoll were first recorded on Macquarie Island by the AAE party on 8 February 1912 when seven birds, of which three were collected, were seen feeding at Sandy Bay. Others were seen at Lusitania Bay and a nest found during the AAE stay. None were seen during the BANZARE visit in 1930. This exotic species is now well established and small flocks can be seen in most parts of the island, from sea level to higher parts of the plateau. Nests have been found in clumps of fern, tall tussock grass and the flower heads of the Macquarie Island cabbage, Stilbocarpa polaris A. Gray [2, 17].

\section{Common Starling, Sturnus vulgaris Linnaeus, 1758}

This species was first positively recorded at Macquarie Island on 2 and 3 December 1930, during the BANZARE visit, when pairs were seen on five occasions. They breed in small groups on rock stacks and cliffs around the island. In winter they form one or more flocks of several hundreds of birds and can be seen feeding on the plateau and in unoccupied penguin colonies $[2,17]$.

\section{Possible identifications}

\section{Double-banded Dotterel, Charadrius bicinctus Jardine \& Selby, 1827}

A bird tentatively identified as a Double-banded Dotterel was seen on The Isthmus in October 1978 [17].

\section{Hooded Plover, Thinornis rubricollis (J.F. Gmelin, 1789)}

One possible sighting of four birds on the reef at the northern end of Sandy Bay in January 1981 [17].

Little Tern, Sternula albifrons (Pallas, 1764)

There is one record of a possible sighting at Bauer Bay, west coast, in December 1975 [17].

\section{Australasian Pipit, Anthus novaeseelandiae (J.F. Gmelin, 1789)}

This is a tentative identification of a bird seen on The Isthmus in July 1978. In 1956 and 1957 "pipits" were also sighted but could not be specifically identified $[6,17]$.

\section{DISCUSSION}

In considering the recorded sightings and the numbers of birds recorded (tables 1 and 2) several factors need to be taken into account. While the records cover over 54 years, during that time there have not always been competent bird observers on the island throughout parts or the whole of every year. The majority of ANARE personnel are based at the Station, on The Isthmus, and through winter periods there were often few observers away from there. Some parts of the island may not be visited for months at a time, or even years along sections of the west coast. The shoreline habitat in the vicinity of Langdon Point and Unity Point provides the most extensive and sheltered environment for shorebirds on the island. It is not surprising therefore that there are numerous records of at least four waders from this seldom-visited locality and this habitat may be even more regularly frequented than is revealed by the records so far. In many cases the number of birds recorded, either monthly or over several months, could be multiple sightings of the same $\mathrm{bird} / \mathrm{s}$. In most cases it is therefore not possible to tell whether apparent changes in the occurrence of a species at the island are real or due to observational/recording effort.

From records covering the period 1901-2000 it has been possible to identify 56 taxa of non-breeding birds and 11 species of rare, exotic or introduced breeding birds at Macquarie Island (tables 1 and 2), excluding the 19 regular breeding species. In addition there are also four species whose identity is doubtful (table 3). Of the 56 non-breeding species 20 are pelagic seabirds and four are exotic species introduced into the Australasian region. The breeding species recorded here consist of seven seabirds, three exotics and one introduced species. The seven breeding seabird species are known to, or likely to, have bred previously on the main island and four appear to be re-establishing there, as control and eradication programs for introduced species, started in the late 1970s, take effect (Brothers \& Copson 1988, Copson 2004, Brothers \& Bone 2008).

Of the 66 positively identified species 14 are holarctic breeding species which migrate to the southern hemisphere during the northern winter period. Seven of these 14 species 
have been recorded on other sub-Antarctic islands. Some, such as the Cattle Egret, appear to be extending their range generally (Crosby 1972, Prince \& Croxall 1983, Trivelpiece et al. 1987).

Thirty-four out of 65 identified species, excluding the introduced flightless Weka, could not, or are unlikely to, rest on the open ocean and must therefore have travelled non-stop from their point of departure to Macquarie Island. The influence on the dispersal of birds of the extreme winds that can occur in the region has been discussed in several papers (Williams 1953, Merilees 1971b, Adamson et al. 1988, Bridgman \& Maddock 1994, Brothers \& Bone 2008). This is well-illustrated with the racing pigeon (Rock Dove above) which was released in Victoria, Australia, on the morning of 29 October 1989 in a race to northern Tasmania. It was caught at the ANARE Station at $10 \mathrm{am}$ on 31 October having covered a distance of at least $2000 \mathrm{~km}$, an unlikely great circle route (PWS unpubl. records). Over this period there had been a strong northwesterly air-stream extending from northern Victoria. The wind at Macquarie Island had increased from a light average wind speed of 7.1 $\mathrm{km} / \mathrm{h}$, maximum gust $48 \mathrm{~km} / \mathrm{h}$ W, on 29 October, through $24.5 \mathrm{~km} / \mathrm{h}$ average, maximum gust $67 \mathrm{~km} / \mathrm{h} \mathrm{NNW}$, on 30 October, to $43.4 \mathrm{~km} / \mathrm{h}$ average, maximum gust $96 \mathrm{~km} / \mathrm{h}$ NNW, on 31 October. The wind run, i.e., the amount of wind passing a fixed point in 24 hours, recorded at the Station up to $9 \mathrm{am}$ on 31 October was $1042 \mathrm{~km}$. The bird appeared in good condition when found.

There are several interesting but unverifiable observations from the earlier literature. In February 1903 the sealers caught at The Nuggets, and ate, what they described as a "white swan" (Cumpston 1968). On 26 May 1913 Anderson, one of the AAE party, reported seeing a "... thrush type bird again at Catch Me Point", (Hamilton 1912-13); was this the first sighting of the Song Thrush or Common Blackbird? Possibly the first sighting of the Common Starling on the island occurred on 8 September 1913 when "... two small birds like starlings" were seen between Sandy Bay and the west coast" (Hamilton 1912-13). In addition in 1983 a glass container, possibly an old food jar, was found in the ruins of the sealers' hut at The Nuggets with a bird preserved in it. The specimen appeared in good condition as the container had a sound cork stopper and was still full of fluid. It was later sent to the Queen Victoria Museum, Launceston, where the cleaned specimen was identified as an immature Black-faced Monarch, Monarcha melanopsis (Vieillot, 1818). It was placed in fresh alcohol and is registered as specimen 1985/2/150. The specimen and container were unlabelled but one possible source was the taxidermist Joseph Burton who worked at The Nuggets, in the penguin oil industry, from 1896-1900 and was permitted to collect specimens in his spare time (Cumpston 1968). If so, it is from before the period under review.

An exotic species management program has been conducted at Macquarie Island since the late 1960 s which, together with climate changes being recorded in these regions, will almost certainly result in changes to the status of many avian species recorded at the island. While detailed scientific studies will be necessary to fully evaluate such changes the contribution of long-term observations and record keeping, whether incidental to the main study, or by scientists working in other fields, keen amateurs or just casual observers, should not be overlooked.

\section{ACKNOWLEDGEMENTS}

This paper is dedicated to Irynej Skira, the first Tasmanian Parks and Wildlife Service representative working at the Macquarie Island Nature Reserve, who did the groundwork and set a very high standard for those of us who followed. Many people contributed to the ANARE, PWS and DPIW logbooks and records and without their effort and enthusiasm this review would not have been possible. The support of the Australian Antarctic Division, Tasmanian Parks and Wildlife Service and Department of Primary Industries and Water made the work possible.

\section{REFERENCES}

Adamsom, D.A., Whetton, P. \& Selkirk, P.M. 1988: An analysis of air temperature records for Macquarie Island: Decadal warming, ENSO cooling and southern hemisphere circulation patterns. Papers and Proceedings of the Royal Society of Tasmania 122 (1): 107--12.

Bourne, W.R.P. 1981: The gadfly petrel skull and diving petrels from Macquarie Island. Notornis 28: 142-143.

Bridgman, H.A. \& Maddock, M. 1994: Meteorological conditions and cattle egret migration: an update. Notornis 41 : 189-205.

Brothers, N.P. 1984: Breeding distribution and status of burrownesting petrels on Macquarie Island. Australian Wildlife Research 11(1): 113-131.

Brothers, N.P. \& Copson, G.R. 1988: Macquarie Island flora and fauna management- interpreting progress and predictions for the future. In Papers and Proceedings of the Royal Society of Tasmania 122(1): 129-135.

Brothers, N. \& Ledingham, R. 2008: The avifauna of Bishop and Clerk islets and its relationship to nearby Macquarie Island. Papers and Proceedings of the Royal Society of Tasmania 142(1): 117-122.

Brothers, N. \& Bone, C. 2008: The response of burrow-nesting petrels and other vulnerable bird species to vertebrate pest management and climate change on sub-Antarctic Macquarie Island. Papers and Proceedings of the Royal Society of Tasmania 142(1): 123-148.

Campbell, A.J. 1901: Nests and Eggs of Australian Birds. The Author, Sheffield.

Christidis, L. \& Boles, W.E. 2008: Systematics and Taxonomy of Australian Birds. CSIRO Publishing, Collingwood: 277 pp.

Copson, G. 2004: Draft plan for the eradication of rabbits and rodents on sub-Antarctic Macquarie Island. Prepared for the Natural Heritage Trust, Department of Environment and Heritage: $76 \mathrm{pp}$.

Cumpston, J.S. 1968: Macquarie Island. ANARE Scientific Reports, Series A (1): 380 pp.

De Lisle, J.F. 1965: The Climate of the Auckland Islands, Campbell Island and Macquarie Island. New Zealand Ecological Society Proceedings 12: 37-44.

Falla, R.A. 1937: Birds. B.A.N.Z. Antarctic Research Expedition 1929-31, Reports, Series B, Vol. II: 288 pp.

Gibson, J.D. 1959: Fork-tailed Swift at Macquarie Island. The Ети 59: 64 .

Gwynn, A.M. 1953: Some additions to the Macquarie Island list of birds. The Emu 53: 150-152.

Hamilton, H. 1912-1913: Biological Dairy kept by Hamilton from $1^{\text {st }}$ January 1912 to $3^{\text {rd }}$ November 1913. Unpublished manuscript in Mawson Papers, National Library of Australia: $133 \mathrm{pp}$.

Jenkin, J.F., Johnstone, G.W. \& Copson, G.R. 1981: Introduced animal and plant species on Macquarie Island. Colloque 
sur les ecosystems subantarctics Paimpont, CNFRA 51: 301-313.

Keith, K. \& Hines, M.P. 1958: New and rare species of birds at Macquarie Island during 1956 and 1957. CSIRO Wildlife Research 3(1): 50-53.

Lindholm, E. 1952: Bar-tailed Godwit at Macquarie Island. The Emu 52(3): 213.

Mawson, D. 1930: The Home of the Blizzard. Abridged Popular Edition. Hodder \& Stoughton, London: 438pp.

Merilees, W. 1971 a: Bird observations - Macquarie 1sland 1967. Notornis 18: 55-57.

Merilees, W. 1971b: Three Song Thrushes at Macquarie Island. Notornis 18: 87-90.

Norman, F.I. 1987: The ducks of Macquarie Island. ANARE Research Notes 42: 22pp.

Prince, P.A. \& Croxall, J.P. 1983: Birds of South Georgia: new records and re-evaluations of status. British Antarctic Survey Bulletin, No. 59: 15-27.

Scott, J.H. 1883: Macquarie Island. Transactions and Praceedings of the New Zealand Institute. 1881, 15: 484-493.
Selkirk, P.M., Seppelt, R.D. \&Selkirk, D.R. 1990: Subantarttic Macquarie Island its Environment and Biology. Cambridge University Press, Cambridge: 285 pP.

Serventy, D.L. 1952: White Egret at Macquarie Island. The Emu 52(1): 66.

Simpson, K.G. 1965: First record of a Grey Plover at Macquarie Island. The Еmu 65(1): 77-78.

Trivelpiece, S.G., Geupel, G.R., Kjelmyr, J., Myrcha, A., Sicinski, J., Trivelpiece, W.Z. \& Volkman, N.J. 1987: Rare bird sightings from Admiralty Bay, King George Island, South Shetland Islands, Antarctica, 1976-1987. Cormorant 15: 59-65.

Warham, J. 1961: A Spine-tailed Swift at Macquarie Island. The Ети 61: 189.

Warham, J. 1969: Notes on some Macquarie Island birds. Notornis 16(3): 190-197.

Williams, G.R. 1953: The dispersal from New Zealand and Australia of some introduced European passerines. Ibis 95: 676-692.

(accepted 24 May 2008) 